\title{
The Relationship between the Constitutional Right to Silence and Confessions in Nigeria
}

\author{
Esa O. Onoja* \\ Nigerian Law School, Bwari, Abuja, Nigeria
}

\begin{abstract}
The extraction of confessions from suspects under torture by security agents is a notorious fact in Nigeria. Ironically, the Constitution of the country guarantees a right to silence, but courts in Nigeria predicate the admissibility of confessions on the common law-based Judges Rules and Evidence Act 2011 without linking it to the constitutionally guaranteed right to silence. This article reviews the legal rules on the admissibility of confessions in Nigeria and contends that without attaching constitutional flavour to the admissibility of confessions, the legislature and the courts in Nigeria unwittingly water the ground for the systemic extraction of confession from suspects in custody in Nigeria. The article suggests that the courts in the country consider the implication of the guarantee of the right to silence in the country's constitution in the determination of the admissibility of confessions to promote fair trial in criminal cases in the country.
\end{abstract}

Keywords

Nigeria; Police; Torture; Confession; Constitution; Right to Silence; Admissibility

\section{Introduction}

Anecdotal evidence suggests that policemen torture suspects to obtain confessions in Nigeria, but reliable empirical evidence to establish the routine extraction of confessions from suspects by policemen to obtain confessions, if available, is hard to access. A fair account of police treatment of suspects in Nigeria may however concede the pervasiveness of such abuse. ${ }^{1}$ The excessive abuse of suspects is a notorious fact ${ }^{2}$ familiar to most members of the Nigerian public and many observers of the modus operandi of the Nigerian Police Force. ${ }^{3}$ Government officials in Nigeria may deny accounts of torture of suspects by foreign organizations

*) E-mail: onojaesa@yahoo.com. Ph.D, B.L., Lecturer, Nigerian Law School, Bwari, Abuja, Nigeria.

1) Accounts of torture, abuse, and extrajudicial killing of suspects by the Nigeria Police Force has been documented. See Network on Police Reform in Nigeria and Open Society, Criminal Force: Torture, Abuse, and Extrajudicial Killings by the Nigeria Police Force (Open Society Institute, New York, NY, 2010), pp. $65-70$.

2) See C. Innocent, 'The Legal Structure of the Police and Human Rights in Nigeria', 14 Third World Legal Studies (1997), 41-70 at 48, where he stated that 'studies have established that the Nigerian Police indulges in illegal interrogation and torture to extract 'confessions' from a criminal suspect.'

3) Human Rights Watch, Rest in Pieces' Police Torture and Death in Custody in Nigeria (July 2005) 17 No.11 (A) Human Rights Watch at p. 28 describing types of torture in Nigeria. 
but studies by Nigerians have affirmed that the average policeman in the country "conceded that in the absence of efficient means of investigating crime, torture is the easiest and most cost effective means of interrogation." ${ }^{4}$ Irrefutable corroboration of such accounts can be found in the transcripts of criminal cases contested in courts in Nigeria. For example, in Ahamba v. State 5 the police shot the appellant in the head. There was no suggestion that he posed a threat or was about to escape. No credible evidence linked him to the armed robbery the Police were investigating. ${ }^{6}$ He signed a statement in hospital while recovering from the bullet injury to his head. He "confessed" to armed robbery, a crime that carries the death penalty in Nigeria. The trial court held that the statement was voluntary because at the time he signed the statement the effects of the torture (the gunshot) had worn off. The trial court admitted the statement in evidence. The appellant was convicted and sentenced to death but the Court of Appeal reversed the verdict on appeal. In Effiong Edet George v. State ${ }^{7}$ the appellant resisted several forms of torture for days before he was taken from the cell with six other suspects at night to lonely spot in Calabar, Cross River State, Nigeria. All the suspects were chained together. The other six suspects were shot to death by the Police. Their blood spilt on the appellant. The appellant "voluntarily" shouted that he would sign a confession prepared by the police. He was forced to carry the corpses of the dead suspects into the police vehicle. The trial judge held that even if a person is tortured he would not know the details of the crime. The "confessional" statement was admitted in evidence and the appellant was convicted of murder and sentenced to death. The Court of Appeal reversed the decision on appeal.

Paradoxically, the abuse of suspects exists despite the fact that Nigeria has entrenched the right to silence in its Constitution. ${ }^{8}$ Like other countries, Nigerian law regard confessions as the best evidence of guilt ${ }^{9}$ but judicial consideration of the admissibility or rejection of confessions in Nigeria does not require any foray to the right to silence, rather the common law-based Judges Rules ${ }^{10}$ and Evidence Act, 2011 regulates admissibility of confessions. ${ }^{11}$ It is difficult to appreciate the

\footnotetext{
4) Innocent, op. cit., note 2 at p. 49.

5) (1992) 5 Nigerian Weekly Law Report (NWLR) (Part 242) $45^{\circ}$.

6) Armed robbery is a capital offence in Nigeria.

7) (2009) 1 NWLR (Part 1122) 325.

8) See Section 35 (2) of the Constitution of the Federal Republic of Nigeria 1999 (CFRN 1999).

9) 'For a statement to amount to a confession it must admit the offence for which the accused is charged. It must, in so doing, be clear, precise and unequivocal.' See Gbadamosi \& Anor V. The State (1992) 2 NSCC 439; Section 28 of the Evidence Act, 2011 provides a statutory definition of a confession.

10) See Ojegele v. The State (1988) Nigerian Supreme Court Cases (NSCC) 276.

11) Originally enacted as the Evidence Ordinance, 1943, it was amended several times before the eventual repeal and replacement by the Evidence Act, 2011. The basic principles of Nigerian confession law have been laid down in numerous cases. See Adekoya v. The State (2013) All Federation Weekly Law Report (All FWLR) (Part 662) 1632 at 1651-1652; Galadima v. The State (2013) All FWLR (Part 667) 630 at 644. See the following cases: Ishma'ilv. The State (2012) All FWLR (Part 609) 1107, holding that a confessional statement must be voluntary to be admissible; State v. Salawu (2012) All FWLR (Part 614) 1 stating that statements
} 
reluctance of the courts and legislature in Nigeria to adapt the country's confessions law in line with the constitutional model she borrowed from the United States. ${ }^{12}$ Custodial interrogations in Nigeria are not regarded by courts as inherently coercive the way they are in the United States and the United Kingdom. Nigerian courts view the admissibility of confessions from the perspective of the Evidence Act and not the stronger constitutional principle ${ }^{13}$ that any person who is arrested or detained shall have the right to remain silent or avoid answering any questions until after consultation with a legal practitioner or any other person of his own choice. ${ }^{14}$

This article reviews statutory provisions, judicial dicta and other rules on the admissibility of confessions in Nigeria, and contend that without according constitutional flavour to the admissibility of confessions, the legislature and the courts in Nigeria unwittingly water the ground for the systemic torture of suspects to obtain confession practiced by the Nigeria Police. It suggests that Nigerian courts consider the implication of the guarantee of the right to silence in the country's constitution before admitting confessions.

\section{Evolution of the Right to Silence and Confession Law in Nigeria}

Evidence of the existence of the right to silence and confession law in the various tribes ${ }^{15}$ that make up modern Nigeria is lost in the mist of time. The current right to silence and the law on confessions in Nigeria originated from the common law of England. ${ }^{16}$ Under the common law, any threat, inducement or force emanating from a person in authority vitiates a confession. ${ }^{17}$ This principle coalesced from the ancient maxim nemo tenetur seipsum accusare, meaning no man is bound to accuse himself or no person need accuse himself. ${ }^{18}$ This "was

to a police officer investigating a case constitutes evidence and that the word 'obtain' connotes coercion; Haruna v. AGF (2012) All FWLR (Part 632) 1617 stating the hallmark of a confession, and validity of confessional statements. In Basseyv. The State (2012) All FWLR (Part 633) 1816 the court restated the rule governing retracted confessions. See also Akpa v. The State (2007) 2 NWLR (Part 1019) 500 where the court stated that where reliable confessions are the strongest means of proof of guilt.

12) Nigeria first adopted a republican constitution modeled after the USA in 1979. The current constitution, the Constitution of the Federal Republic of Nigeria, 1999 (CFRN 1999), as amended, has followed that tradition.

13) The United States Supreme Court held in Counselman v. Hitchcock, 142 U.S. 547 (1892) held that the rules of inadmissibility created by statues are inferior to similar rules in the constitution in the sense that the grant lower protection.

14) See Section 35 (2) CFRN, 1999 as amended.

15) Nigeria consists of more than 250 tribes.

16) Nigeria was a British colony from about 1861 to 1960 when the country attained independence.

17) See $R v$. Sykes (1913) 8 CAR 233; $R v$. Warickshall 163 E.R 234.

18) But in its earliest conception 'the principle that no person should be compelled to betray himself in public was a check on overzealous officials rather than a subjective right of anyone who was accused of a crime.' See E. Kinnider, The Art of Confessions: A Comparative Look at the Law of Confessions-Canada, England, The United States and Australia (International Centre for Criminal Law Reform and Criminal Justice 
the English... reaction against an investigative and prosecutorial excess known as the "oath ex officio"19 which was used initially by Inquisitors as an investigative and adjudicative weapon to extract confessions and self incriminating testimony under oath. ${ }^{20}$ The oath was also used to quench religious and political dissent by the Court of Star Chamber and the Court of High Commission in England. ${ }^{21}$ The Court of Star Chamber and the oath ex officio were later abolished by Parliament. ${ }^{22}$ The principle that "No man shall be required to accuse himself' became a first principle of English liberty"23 following the abolition of the oath ex officio.

Originally, the right to silence was both an expression of individual autonomy and a device for the protection of the individual from the excesses of government officials during investigation and trial. In $R v$. Director of the Serious Fraud Office ${ }^{24}$ Lord Mustill acknowledged this fact and elucidated the exegesis of the right of silence as follows:

I now turn from the statutes to "the right of silence." This expression arouses strong but unfocused feelings. In truth it does not denote any single right, but rather refers to a disparate group of immunities, which differ in nature, origin, incidence and importance, and also as to the extent to which they have already been encroached upon by statute.

Lord Mustill further observed that the right to silence during interrogation is directed, inter alia, at preventing inquisition and the admission of exra-judicial confessions that are not proved by the state to be the product of an accused person's free will. ${ }^{25}$ This vital linkage of the right to silence to the admissibility of confessions is missing from judicial dicta in Nigeria.

The right to silence was introduced into the Constitution of the United States by the $5^{\text {th }}$ Amendment which provides, inter alia, that no person shall be compelled in any criminal case to be a witness against himself. The right is entrenched in Section 35(5) of the CFRN 1999. One purpose of the right to silence is to protect the citizen from torture and coerced confessions. Confessions induced by torture are

\footnotetext{
Policy, Vancouver, BC, 2005), 4, available online at www.icclr.law.ubc.ca/Publications/Reports/Es\%20... PDF (last visited 10 July 2011).

19) C.E. Moylan and J. Sonsteng, 'The Privilege Against Compelled Self-Incrimination', 16 William Mitchell Law Review (1990), 249-308, at 253.

20) Ibid., at 254.

21) Ibid.

22) 'John Lilburne is credited with the final abolition of the oath ex officio. See L. Griffin, 'I Silence Sacred: The Vulnerability of Griffin V. California in a Terrorist World', 15 William \& Mary Bill of Rights Journal (2007), 927-962, at 931. See also K. Lasson, 'Torture, Truth Serum, and Ticking Bombs: Toward a Pragmatic Perspective on Coercive Interrogation', 39 Loyola University Chicago Law Journal (2008), 329-36o, at 332.

23) See Moylan and Sonsteng, supra note 18.

24) (1992) WLR 66 at 74.

25) Lord Mustill also traced the right to the abolition of the Court of Star Chamber. Ibid., at p. 75.
} 
considered unreliable because they are unsafe and violate individual autonomy and also involve abuse of governmental powers. ${ }^{26}$

Nigeria shares some constitutional principles with the United States, but Nigerian confession law originated from England. In England, the iniquities of the ancient system so impressed itself on the English people that it led to "a general and silent acquiescence of the courts in a popular demand ... [that] made a denial of the right to question an accused person a part of their fundamental law ..."27 The common law rules on the admissibility of confessions have been stated in numerous cases in Nigeria. ${ }^{28}$ A confessional statement freely made is regarded as the strongest form of evidence, presumably because it proceeds from the mind of a person burden by guilt who desires to make a clean breast of the weight of guilt. ${ }^{29}$ The onus of proof is however on the state to prove that a statement is voluntary or was not taken under oppressive circumstances. Where the accused person retracts a confession, a court can admit the statement and base its decision on it, but it is desirable that the court examines evidences outside the confession to see if it is probable that the accused person committed the crime. ${ }^{30}$

Where the accused person challenges the voluntariness of a confessional statement, the court must conduct a trial with trial or voire dire to determine the voluntariness of the statement. ${ }^{31} \mathrm{~A}$ judge must determine the question of admissibility based on the peculiar facts of each case. ${ }^{32}$ But in considering the circumstances of the taking of the statement, the court must not determine the rule as to voluntariness in such a way as to be "a clog on the proper exercise by the police of their investigating function, and, indeed, on the administration of justice itself." ${ }^{33}$

26) L.E. Chiesa, 'Beyond Torture: The Nemo Tenetur Principle in Borderline Cases', 30 Boston College Third World Law Journal (2010), 35-66, at 36-37 where she discussed the rationale for the rejection of coerced confessions.

27) Brown v. Walker, 161 U.S. 591, 596-597 (1896) quoted by Chief Justice Warren in Miranda v. Arizona, 384 U.S. 436 (1966) The above quotation is actually too broad as it is a fact that the courts in England have not prevented the Police from interviewing or questioning detainees. Only inappropriate tactics of interrogation are forbidden. On the current position of Miranda in the U.S. see C.D. Weisselberg, 'Mourning Miranda', 96 California Law Review (2008). 1519-1604.

28) See, for instance, Saidu v. The State (1982) 4 Supreme Court (S.C) 41; Emeka v. The State (2001) 6 S.C 227; Alarape v. The State (2001) 2 S.C 114.

29) See Egboghonome v. The State (1993) 7 NWLR (Part 306) 383 .

30) See Demo Oseni v. The State, (2012) 5 NWLR (Part 1293) 351 S.C; See also Onwumere v. The State (1991) 4 NWLR (Part 186) 428 at p. 440. Some scholars have argued that all confessions be corroborated before they are used by courts. See R. Pattenden, 'Should Confessions be Corroborated?', 107 Law Quarterly Review (1991), 317-339.

31) But there are no hard and fast rules for determining voluntariness. Each case must be assessed from the totality of the circumstances in which the statement was made. For a discussion of the underlying principles for the determination of voluntariness in the U.S. see P. Marcus, 'It's Not Just About Miranda: Determining the Voluntariness of Confessions in Criminal Prosecutions', 40 Valparaiso University Law Review (2006), 601-644.

32) See DPP v. Ping Lin (1975) 3 All ER 175 at 178 (H.L).

33) Ibid. Per Lord Hailsham at p. 183. 
Oputa, J. ${ }^{34}$ in The State V. Madukolu ${ }^{35}$ observed that: "While it is desirable in the interest of the community that investigations into crimes should not be unduly cramped, it is equally desirable in the interest of justice that as against the accused every rule in his favour should be observed and that no rule be broken so as to prejudice the chances of the court fairly trying the true issues."

\subsection{The Introduction of the Judges Rules in Nigeria}

It was perhaps in a bid not to balance the interest of the state with that of suspects that the common law judges established the Judges Rules of 1912. ${ }^{36}$ The rules permit the questioning of suspects or accused persons in the course of investigation of crimes. But where the police decide to charge the person, they must warn him that he is not bound to say anything, but that if he says anything, what he says will be taken down and may be used in evidence. ${ }^{37}$ Other aspects of the Judges Rules stipulates the manner of taking of statements, and require the police to bring to the attention of a suspect statements made by other suspects incriminating him. ${ }^{38}$ But the rules are for administrative convenience and failure to comply with the Rules would not vitiate a confession that is voluntary. ${ }^{39}$

The courts in Nigeria have held that the Judges Rules are applicable in Nigeria, ${ }^{40}$ or more correctly speaking, to the states in the southern part of Nigeria where the Criminal Procedure Act ${ }^{41}$ govern criminal proceedings. In the northern states, the relevant rules are contained in the Criminal Procedure (Statement to Police Officers) Rules $1960 .{ }^{42}$ Unlike the Judges rules that are regarded as guides to the police the breach of which is not necessarily fatal to the admissibility of the confession, Rule 9 of the Criminal Procedure (Statement to Police Officers) Rules provides that: "Save as provided by the Evidence Ordinance, no statement made to a police officer by a person against whom he has decided to make a complaint shall be admissible in evidence in any court unless such statement is made in accordance with these rules" 43 In Lagos State, the relevant rules are contained in Sections 3 and 9 (3) of the Administration of Criminal Justice Law of Lagos State, 2011. The provisions of this law restate Section 35(2) of the CFRN 1999 and further requires

\footnotetext{
34) He rose to the bench of the Supreme Court of Nigeria.

35) Per Oputa, J. in The State v Madukolu (1972) 2 East Central State Law Report (Part 2) 623.

36) The original Judges Rules were four, but these were expanded to nine in 1918.

37) See $R v$. Osborne (1973) 1 All ER 649.

38) See T.A. Aguda, The Law of Evidence in Nigeria (Sweet \& Maxwell, London, 1974), pp. 48-52.

39) See Ojegele v. The State (1988) 1 NWLR (Part 71), 414 at 423-424.

40) See Usman v. The State (1981) 2 Nigerian Criminal Report 335.

41) Laws of the Federation, Chapter $\mathrm{C}_{41}$ (2004).

42) See the dictum of Uwais Chief Justice of Nigeria (CJN) in Ozaki V. The State (1990) All Nigeria Law Report (All NLR) 94.

43) See Jona Dawa v. The State (1980) NSCC 334 where the Supreme Court stressed that the Judges Rules operates only in the states that use the Criminal Procedure Act.
} 
audio or video recording of confessions where there the suspect's counsel is not present during the questioning. ${ }^{44}$

\section{The Rules of Admissibility of Confessions Under the Nigerian Evidence} Act 2011

The common law rules on confession were codified in Sections 27 to 32 of the Evidence Act, 1990. ${ }^{45}$ The 2004 version was repealed and replaced by the Evidence Act 2011. The basis of admissibility of confessions under the 1990 Act was the voluntariness of the confession. ${ }^{46}$ The basis for the admissibility of confessions under the 1990 Act was voluntariness while Section 29 of the 2011 Act predicates admissibility of confessions on reliability determined by the presence or absence of oppressive circumstances during the making of the confession. Oppression under the Act includes torture, inhuman or degrading treatment, and the use of threat of violence whether or not amounting to torture. ${ }^{47}$

\subsection{The Tests for Determining Admissibility of Confessions in Nigeria}

In every case, the court must be satisfied that the confession is reliable before it is admitted in evidence. The mere fact that an accused person retracts a confession does not make it inadmissible. ${ }^{48}$ In Alarape $v$. The State, ${ }^{49}$ the Supreme Court of Nigeria held that the court should not act on a confession without first testing it. The tests to determine the veracity of confessions are:

(a) Whether there is anything outside the confession to show that it is true;

(b) Whether the statement is corroborated, no matter how slightly;

(c) Whether the facts contained therein, so far as can be tested, are true;

(d) Whether the accused person had the opportunity of committing the offence;

(e) Whether the confession of the accused person is possible;

(f) Whether the confession was consistent with other facts which have been ascertained and proved in the matter. ${ }^{50}$

44) More on this infra below (Sections 4.1 and 5).

45) This Act was originally enacted as the Evidence Ordinance No. 23 of 1945. It was based principally on the 12th edition of Stephen's Digest of the Law of Evidence, which came into operation on 1 June 1945.

46) See Igriv. The State (2011) All FWLR (Part 563) 1960.

47) See Section 29 (5) of the 2011 Evidence Act.

48) 'A mere denial without more, even at the earliest opportunity, cannot, on the facts of this case, lend weight to the denial. The denial is a bare statement bereft of any supporting fact and standing only on the ipso dexit of the appellant.' Per Ngwuta, Justice of the Supreme Court (JSC) in Demo Oseni v. The State, supra note 30.

49) (2001) 2 S.C114, at 125 .

50) Ibid., at 126. See also Onochiev. The Republic (1966) Nigeria Monthly Law Report (NMLR) 307; Ikemsonv. The State (1989) 3 NWLR (Part 110) 455; Edamine v. The State (1996) 3 NWLR (Part 438) 530 Akpan v. The 
The above principle suggests that it is desirable for courts to seek corroboration outside confessions before acting on it. ${ }^{51}$ This principle is however a recommendation so that if a court failure by a court to adhere to it does not vitiate the confession or a conviction based on such confession. ${ }^{52}$ The point for an accused person to challenge the admissibility of a confessional statement is when the prosecution applies to tender it. ${ }^{53}$ Failure to object to its admissibility renders the statement admissible. ${ }^{54}$ But where the accused person alleges that the statement was induced by oppression the court must conduct a trial within trial. ${ }^{55}$ Failure to conduct a trial within trial vitiates the statement. ${ }^{56}$ The onus of proof of admissibility in that situation is on the prosecution. ${ }^{57}$ The court must deliver a ruling after the trial within trial and not postpone the ruling to the conclusion of the substantive case. ${ }^{58}$

\subsection{The Procedure at the Voire Dire}

The prosecution ought to lead evidence before the defense to prove the circumstances of the making of the confession. However, courts in Nigeria have not been consistent as to the effects of the breach of the procedure in a trial within trial. While some courts hold that calling upon the accused person to first lead evidence in the trial within trial is irregular and vitiates the trial, other courts hold that such breach may not necessarily result in the exclusion of confessional statements if the accused person suffered no prejudice. ${ }^{59}$ It is submitted that calling on the accused person to open the trial within trial amounts to shifting the onus of proof that should lead to the rejection of the confession on appeal, or at best an order of a retrial.

The purpose of a trial within trial is to test the circumstances of the making of the confession. It is the usual practice in Nigeria for the Investigating Police Officer (IPO), who usually records statements, to take the accused person with

\footnotetext{
State (1992) 6 NWLR (Part 243) 439; Nwaebonyi v. The State (1994) 5 NWLR (Part 343) 138; Adekoya v. The State, supra note 11, p. 3; Galadima v. The State, supra note 11.

51) For the theoretical argument on the need for confessions to be corroborated, see Pattenden, supra note 30 .

52) See Adekoya v. The State, note 11 at $165^{2}$.

53) In Demo Oseniv. The State, supra note 30, the counsel to the accused person stated when an application to tender the confessional statement as follows: 'The 2nd accused said he did not sign the statement and I know that does not stop it from being admitted.' Held dismissing the appeal that the accused was bound by his confession since there was no objection that the statement was not made voluntarily. See also Mbang v. The State (2011) All FWLR (Part 562) 1766 at 1787 where the Court of Appeal held that the proper time to challenge the admissibility of a confessional statement is when it is sought to be tendered.

54) Igriv. The State, supra note 46, at 1983-1984.

55) Nwachukwuv. The State (2004) 17 NWLR (Part 902) 262 at 273.

56) See Obidioso v. The State (1987) 4 NWLR (Part 67) 48.

57) Emekav. The State (2001) 6 S.C 227 at 232.

58) See Dele v. The State (2011) 1 NWLR (Part 1229) 508.

59) Emeka v. The State, supra note 20, at 233; Gbadamosi \& Anor v. The State, supra note 9.
} 
the written confessional statement to a superior police officer for confirmation. But this practice is a convention and not a requirement of law. The recorder of the statement and the superior police officer before whom the confession was allegedly confirmed are necessary witnesses in a trial within trial. ${ }^{60}$ But failure to call the superior police officer who attested to the statement as a witness is not necessarily fatal to admissibility. ${ }^{61}$ When a statement is made in a language other than English the interpreter and recorder are also necessary witnesses to the determination of admissibility of the statement. ${ }^{62}$ But courts should be cautious even when the IPO and the confirming officer testify because they have been known to be clever by half. ${ }^{63}$

Justice Oputa ${ }^{64}$ in The State v. Madukolu ${ }^{65}$ advised on what is expected of a superior police officer when confirming a confessional statement as follows:

(a) The practice should demonstrate that the maker of the statement was a free agent and not a victim of any threat or coercion

(b) In serious cases like murder, the superior police officer before whom an accused person is brought has a duty to conduct an impartial inquiry to satisfy himself that the alleged confession was indeed voluntary;

(c) It is desirable that the superior police officer adhere to the practice of writing down what questions they asked the accused and his answers thereto, questions as to the usual and necessary cautions, questions as to whether the accused indeed made the confession voluntarily of his own free will;

(d) In addition, the statement should then be read to the accused sentence by sentence and the accused should be asked if he wishes to add to, or alter anything in the statement;

(e) His answers to these questions should again be recorded;

(f) If the statement is to be interpreted to the accused, it is advisable and undesirable to use as an interpreter the same policeman who recorded the alleged confession;

(g) At the end of such enquiry, the superior police officer should then sign the record he had made and the accused should also sign or thumb impress the record.

60) In Amachree v. Nigerian Army (2003) 3 NWLR (Part 807) 256, it was held that where an allegation of inducement is made against the investigating officer, failure to call him results in rejection of the statement.

61) Egboghonomev. The State, supra note 29.

62) See Federal Republic of Nigeria (FRN) v. Usman (2012) All FWLR (Part 632) 1639 at 1644.

63) Note that in Ahambav. The State (1992) 5 NWLR (Part 242) 450 both the Investigating Police Officer (IPO) and a Superior Police Officer testified that the statements of the appellant were voluntary despite the fact that they shot him in the head before he 'volunteered the statement.'

64) Justice Oputa retired as a Justice of the Supreme Court of Nigeria.

65) Supra note 35 . 
Where the above practice is adhered to, such record would strengthen the case for the prosecution in a trial within trial and provide materials for the court to do justice in the matter. It is remarkable that in Nigeria failure of the police to keep detailed dossier of an investigation is not fatal to the credibility of such investigations. Courts do not, as a practice, call for the diary detailing police investigation before admitting confessions, not even where the confession is challenged by an accused person charged with a capital offence. This places accused persons at a disadvantage in relation to the state. Where an alleged confessional statement is not properly scrutinized with the chronology of events in a case diary an innocent person may be wrongly convicted. ${ }^{66}$

An established police practice in Nigeria that makes it difficult for courts to shake off the conclusion that a statement was freely made, is the recounting of the life and family history of the accused person immediately after the words of caution before the admission of culpability in the body of the statement. Courts sometimes have no way of knowing that the life history was given while the suspect was suspended upside down on a ceiling fan hook, or signed the statement at an isolated spot out of town around $2 \mathrm{AM}$ with a gun pointed to the head, or worse still, with other suspects lying dead in a pool of their own blood. ${ }^{67}$ For instance, in State v. Dickson Ajayi, ${ }^{68}$ there was evidence in the voire dire from the prison nurse, and cell mate of the accused that he was bleeding from the anus, and had several other injuries on his body inflicted during police torture. There was also undisputed evidence that the accused was taken to a "torture room" at the Federal Investigation and Intelligence Bureau, Alagbon Close, Ikoyi, Lagos, where the accused was knocked unconscious by PW 19 in the presence of Deputy Inspector General of Police, Parry Osayande. ${ }^{69}$ The trial court rejected the alleged confessional statement as involuntary. The Court of Appeal affirmed the decision. Also, in Yusuf Ibrahim Garko v. State ${ }^{70}$ the police tortured the arrestee to death. ${ }^{71}$ But the killer policeman was not tried for murder. Instead, he was tried, convicted, and sentenced to five years imprisonment for a lesser offence. It is therefore submitted that before a confessional statement is admitted in a trial within trial, the police should be compelled to give a blow by blow account of the events leading to the confession.

\footnotetext{
66) See Mbang v. The State, supra note 53, where an innocent man would have faced the gallows if the Supreme Court had not reviewed the procedure at the trial court.

67) See George v. The State (2009) 1 NWLR (Part 1122) 325, and Ahamba v. The State, supra note 5.

68) (1997) 5 NWLR (Part 505) 382.

69) Mr Parry Osayande retired as a Deputy Inspector General of Police, and recently retired as the Chairman of the Nigerian Police Service Commission. He has served in several committees established by the Federal Government of Nigeria to reform the Police.

70) (2006) 6 NWLR (Part 977) 524.

71) Also in Ogbodo v. Inspector General of Police (IGP) (1997) Federal High Court Law Report 367, the claim of torture against the police succeeded.
} 
Unfortunately, even when there is proof of coercive interrogation, a confession may still be admissible in Nigeria if it was not the torture or inducement that spurred the confession. The law of causation applies. ${ }^{72}$ Statements recorded in prison are also admissible. ${ }^{73}$ It is submitted that torture and detention taint confessions. Courts in Nigeria have not commented on the phenomenon of false confessions and police trickery during interrogations. The fact that custody may lead to false confessions have also not been addressed by courts in Nigeria. ${ }^{74}$ Awareness of the risks of false confessions should weigh in considering confessions from the lens of the constitutionally guaranteed right to silence in a manner that protects suspects in custody. The opportunity for the Supreme Court of Nigeria to give a constitutional flavour to confession law in the country came in Fatai Olayinka v. The State. ${ }^{75}$ The appellant contended that the confession "whilst the appellant was in custodial police interrogation [was] contrary to the provisions of Section 35 (2) of the 1999 Constitution..." The lead judgment did not refer to this issue or the argument that the court should invoke the decision of the U.S. Supreme Court in Mirandav. Arizona.$^{76}$ Rather, the supporting judgment of Tobi JSC, which referred to the argument, observed that the issue had been over taken by events. Thus the CFRN is the highest law in Nigeria but the guarantee to silence plays second fiddle to statutes and court decisions in the admissibility of confessions.

\subsection{Silence and Pre-Interrogation Caution in Nigeria}

There is lack of consistency by Nigerian courts as to whether a caution is mandatory before questioning. The dominant position of courts, however, is that a confession is not necessarily inadmissible because there was no caution or warning preceding the taking of such confession. ${ }^{77}$ It also does not affect admissibility whether or not the confession was made while the accused was detained incommunicado. ${ }^{78}$ But the absence of the caution might weigh in the decision whether or not to admit the statement. ${ }^{79}$ Trial courts are therefore enjoined to look for the words of caution in determining what weight to ascribe to retracted confessions. This position apparently conflicts with Section 35(2) of the CFRN 1999 that

\footnotetext{
72) See Jona Dawa v. The State, supra note 43.

73) See Nwali Nnabo v. The State (1992) 2 NWLR (Part 226) 716 and Arogundare v. The State (2009) 6 NWLR (Part 1136) 165.

74) For a review of investigative manipulation and deception see J.H. Skolnick and R.A. Leo, "The Ethics of Deceptive Interrogation', 11 Criminal Justice Ethics (1992), 3-12, where they stated, inter alia, that: 'Contemporary police interrogation is routinely deceptive.' See also M.S. Gohara, 'A Lie for a Lie: False Confessions and the Case for Reconsidering the Legality of Deceptive Interrogation Techniques' 33 (3) Fordham Urban Law Journal (2005), 101-150, where she pointed out that deception can lead to false confessions.

75) (2007) 9 NWLR (Part 1040) 561.

76) Supra note 27.

77) Akinmogu v. The State, (200o) 6 NWLR (Part 662) 608 at 617.

78) Nwali Nnabo v. The State, supra note 73.

79) Kim v. The State (1992) 1 NSCC 581.
} 
expressly enjoins a right to silence to every person who is arrested or detained. This right may be waived, but how does the average suspect among a population that is not literate in English, the official language of Nigeria, know of the existence of this right when courts do not insist that the police draw the attention of suspects to this right before accusatorial questioning? ${ }^{80}$

The United States Supreme Court, with whom Nigeria shares fundamental constitutional principles, has confronted the constitutional implication of the right to silence and right to counsel in the context of police interrogation. In Haynes $v$. Washington $^{81}$ the U.S. Supreme Court held that, under a totality of circumstances test, where it is proved that the accused was "alone in the hands of the police, with no one to advise or aid him, and he had no 'reason not to believe that the police had ample power to carry out their threats, ... to continue, for a much longer period if need be, the incommunicado detention ... [n] either the petitioner's prior contacts with the authorities nor the fact that he previously had made incriminating oral admissions negatives the existence and effectiveness of the coercive tactics used in securing the written confession introduced at trial." The court went on to observe that incommunicado interrogations are unfair and inherently coercive and that any confession taken in such context cannot be the product of a free and unconstrained will. ${ }^{82}$ In Miranda v. Arizona ${ }^{83}$ the U.S. Supreme Court conceded the difficulty of determining what exactly happens in the interrogation room, ${ }^{84}$ but advanced its reasoning in Haynes ${ }^{85}$ further by holding that incommunicado interrogations are not only inherently coercive but the fruits of such interrogation are vitiated if the police fail to administer a four-fold warning before custodial interrogation. The court held, inter alia, that the admissibility of statements obtained from an accused in custody raises a constitutional issue and that the prosecution may not use confessional statements "stemming from custodial interrogation of the defendant unless it demonstrates the use of procedural safeguards effective to secure the privilege against self-incrimination. By custodial interrogation, we mean questioning initiated by law enforcement officers after a person has been taken into custody or otherwise deprived of his freedom of action in any significant way."

Eugene Milhizer has provided some compelling rationale for Miranda that supports the synthesis of the right to silence and confession law. These rationale include the presumption that formal police questioning in a custodial setting is informally coercive, and to ameliorate the latent compulsion, certain warnings

\footnotetext{
80) Questioning is accusatorial if the interviewee is a suspect and not merely a potential witness.

81) 373 U.S. 503 (1963).

82) Supra, per Mr. Justice Goldberg, at p. 515.

83) Supra note 27.

84) For a discussion of the context of interrogation and what goes on inside the interrogation room, see R.A. Leo, 'Inside the Interrogation Room', 86 Journal of Criminal Law and Criminology (1996), 266-302. 85) Op. cit.
} 
are required to "preserve the suspect's capacity to exercise free will in dealing with the police." ${ }^{\prime 86}$ But several exceptions to Miranda have been devised by the Supreme Court of the U.S due largely to the criticism that the Miranda doctrine unduly favours the guilty and hamstrings law enforcement. ${ }^{87}$ The most notorious exception was introduced in New York v. Quarles ${ }^{88}$ where the court, held that "overriding considerations of public safety justify the officer's failure to provide Miranda warnings before he asked questions..." ${ }^{89}$ The Supreme Court of Canada has held, like the U.S. Supreme Court, that the right to silence is an integral part of confession law thus blending the right to silence and the rules for the admissibility of confessions. ${ }^{90}$

While Nigerian law permits interrogation without a caution, any confession "obtained" by the police is deemed coercive and involuntary. ${ }^{91}$ The test, in this narrow context, is the use of the word "obtain" by the Investigating Police Officer during a trial within trial or in describing the taking and recording of the statement in the substantive case. ${ }^{92}$ There appears also to be some judicial confusion as to the value or import of the phrasing of the caution or warning preceding interrogation. While some dicta suggests that the words of caution, if phrased wrongly, may be an inducement to speak that renders a confession inadmissible, ${ }^{93}$ other dicta suggests that the cautionary words are a desideratum. ${ }^{94}$ It is submitted that the caution is fundamental to the admissibility of confessions because its presence raises a presumption that the constitutional right to silence was respected, but waived. Without the words of caution, a confessional statement should be rejected for violating the constitutional right to silence. This is a better guide to the police than the exclusion of statements on the basis of the use of the word "obtained" ${ }^{95}$ In an environment of pervasive use of the "third degree" or torture by the police, ${ }^{96}$ any confession that is tainted should be rejected. But it is equally true that an average police man may not necessarily understand the nuances of fine English words like

86) E.R. Milhizer, 'Rethinking Police Interrogation: Encouraging Reliable Confessions While Respecting Suspect' Rights', 41 Valparaiso University Law Review (2006), 1-108, at 15.

87) For a rich critique of the arguments for and against Miranda, see S.B. Duke, 'Does Miranda Protect the Innocent or the Guilty', 10 Chapman Law Review (2006-2007), 551-577.

88) 467 U.S. 649, 104 S. Ct. 2626 (1984).

89) Ibid., at p. 651 .

90) See R. v. Singh, (2007) 3 S.C.R. 405 , 285 D.L.R (4th) 583 (hereafter Singh). For a full discussion of the place of the right to silence in Canadian confession law, see H. Stewart, "The Confessions Rule and the Charter', 54 McGill Law Journal (2009), 517-546.

91) See Onobu v. IGP (1957) Northern Nigeria Law Report (NNLR) 25.

92) See $R v$. Nyinya Kwaghbo (1962) Northern Region of Nigeria Law Report (N.R.N.L.R.) 4.

93) See $R v$. Nimiel Viaphong (1961) NNLR 47, at pp. 47-48.

94) See Chukwuka Ogudov. The State (2011) 18 NWLR (Part 1278) 1.

95) See The State v. Salawu, supra note 12, where Supreme Court stated that the word 'obtain' connotes a demand which vitiates voluntariness of a statement.

96) Proof of torture by the police in Nigeria can be found in many cases. See for instance, George $v$. The State, supra note 7 , where the appellant was tortured by beating and hanging, use of hot iron on his stomach, murder of six arrestees in his presence, etc. 
"obtain". Before a court excludes a confession on the basis that it was "obtained", the entire facts and circumstances of the taking of the confession, including the atmosphere of the interrogation, the individual characteristics of the accused, the time and place of the interview, the particular conduct of the officers who conducted the interrogation should be reviewed. ${ }^{97}$ But more strongly on the point, Section 31 of the Evidence Act, 2011, uses the word "obtaining" in describing the taking of confessions. The draftsman appears to disagree with the conventional judicial wisdom that the word "obtain" connotes coercion, a pointer to the artificial credence lent to the word "obtain" by courts.

The nuances of the taking of confessions and the inherent breach of the right to silence are sometimes not given the attention it deserves by courts in Nigeria. In Arogundare v. The State ${ }^{98}$ the Supreme Court of Nigeria held that an oral confession made to a senior police officer at $2 \mathrm{AM}$ while the appellant was in custody was admissible, particularly as "the appellant and his counsel... for reasons best known to them failed to challenge it." 99 It is difficult to fault the reasoning and conclusion of the Supreme Court when the accused and his counsel did not challenge the evidence during the trial. However, the case raises issues relating to the propriety of the surrounding circumstances of the making of confessions in Nigeria and deceptive interrogations. ${ }^{100}$ The trial court, the Court of Appeal, and Supreme Court did not raise the question of what motivated a son to kill the father. None of the courts mentioned the absence of an autopsy report disclosing the presence of the sleeping pills in the system of the deceased. There is nothing in the reported decision adverting to the towel that was allegedly used to suffocate the deceased. Typical of the Nigerian Police, no DNA evidence was tendered in the matter. There was also no forensic evidence to reveal the tell-tale signs of suffocation to solidify the "oral confession" of the appellant. The courts did not consider why it was necessary to cover the mouth of a person who had been drugged to sleep as alleged by the State. If the victim died of suffocation as suggested by the confessional statement, no inquiry was made to explain this conflict with the facts stated in the confession. No questions were asked as to why the visit to the police station was made at $2 \mathrm{AM}$ and not in the day time. No alarm was raised that the oral confession should not be a substitute for routine investigative work in murder cases to ensure that the wrong person is not implicated. ${ }^{101}$ Documented shoddy police investigation in Nigeria, sometimes lending credence to the suspicion that there was spirited design to shield the real culprit supports the need for caution in

\footnotetext{
97) The Court of Appeal recently adopted this approach in Dairo v. F.R.N (2013) All FWLR (Part 663) 1921 at 1967 paras A-E, pp. 1970-1971, paras G-G and held that the condition of detention of the appellant and the manner of interrogation by the Economic and Financial Crimes Commission were coercive.

98) (2009) 6 NWLR (Part 1136) 165.

99) Ibid.

100) On the danger of false confessions from deceptive interrogation, see Gohara, supra note 74.

101) The U.S. Supreme Court stated the use of confessions as short cut in Haynes v. Washington, 373 U.S.503,519 (1963).
} 
accepting police evidence of confessions. ${ }^{102}$ It should therefore be borne in mind that the details of crimes are not necessarily proof that the confession is reliable. False confessions have been found to sometimes contain "rich, detailed, and accurate information." 103 The Police are also known to program suspects using coercion and suggestion to implant the details of crimes in their minds "so that the suspect can then parrot back an accurate-sounding narrative."104

\section{The Changes Made to Nigerian Confession Law by the Evidence Act 2011}

Admissibility of confessions under the provisions of the Evidence Act 1990 was based on voluntariness. Section 29 of the Evidence Act now predicates the reception of confession in Nigeria on reliability. ${ }^{105}$ Under Section 29 of the 2011 Act, where it is represented to the court that the making of the confession was actuated by the oppression of the maker, or the circumstances of the making thereof renders it unreliable, the court shall reject the confession. The draftsman of the 2011 Act borrowed Section 76 of the Police and Criminal Evidence Act, PACE, 1984 of England and Wales, Section 29 of the 2011 Act being almost a verbatim reproduction of Section 76 of PACE. The policy behind PACE, as stated in $R v$. Samuel 106 is to ensure that persons in police detention are not denied the right to silence and to consult a lawyer in private provided by Section 58 of PACE. Where the right is denied, it can lead to the exclusion of confessions from such unlawful interviews unless the prosecution satisfies the court that the denial was not oppressive. In England the right to consult a lawyer before and during questioning is "one of the most important and fundamental rights of a citizen."107

There is no provision in the Evidence Act, 2011 similar to Section 58 of PACE. Also, under Section 82(1) of PACE, where a statement contains an admission and exculpatory statements, both are admissible and if the prosecution subsequently shows that the exculpatory portion is false, the court can draw adverse inferences against the accused..$^{108}$ There appears no sound reason why the terms of the definition of confession in Section 82 of PACE was not adopted in the Evidence Act 2011.

Since Section 29 of the 2011 Act is largely taken from the provisions of Section 76 of PACE, a review of the PACE provisions on confessions and the case law it has generated is useful for a full appreciation of the import of the provisions of Section 29

102) See Delev. The State, supra note 58 , where rather than arresting the real culprits, the police coerced the appellant to confess to murdering his wife. Eye witnesses pointed to the innocence of the appellant but the police ignored them. He was saved by the reversal of the decision of the lower court on appeal.

103) B.L. Garrett, 'The Substance of False Confessions', 62 Stanford Law Review (2010), 1051-1119, at 1054.

104) Ibid., at 1053 .

105) But see Ogheneovo v. The State, (2013) All FWLR (Part 667) 704, at 735 where the Court of Appeal observed that Section 28 of the 1990 Act has been replaced by Section 29(2) of the 2011 Act without mentioning the subtle change in the rules of admissibility of confessions in Nigeria.

106) (1988) 1 QB 615; (1988) 2 All ER 135.

107) Ibid.

108) See Rv. Sharp (1988) 86 Cr. App R274. 
E.A. 2011. The impact of PACE on the confession law of England and Wales has been reviewed by eminent scholars ${ }^{109}$ so only a brief stated of some of the provisions of PACE would be made here for the purpose of indicating the possible interpretation of Section 29 of the Evidence Act 2011. Section 76(2) provides that, if in any proceedings where the prosecution proposes to give in evidence a confession made by the accused, it is represented to the court that the confession was or may have been obtained by oppression of the person who made it, or there were circumstances existing at the time, to render unreliable any confession which might be made by him in consequence thereof, the court shall exclude the statement. ${ }^{110}$

Section 66 of PACE empowers the Secretary of State (England) to issue Codes of Practice in connection with, inter alia, the detention, treatment, questioning, and identification of persons by police officers. ${ }^{111}$ Section $67(11)$ of PACE, provides that in all criminal and civil proceeding, any such Code shall be admissible in evidence, and if any such code appears to the court or tribunal conducting the proceedings to be relevant to any question arising in the proceedings it shall be taken into account in determining that question. Code $\mathrm{C}$ made pursuant to that power regulates Detention, Treatment and Questioning of Persons. Under Code C it is mandatory for the detainee to be warned of his rights, including the availability of counsel. A contemporaneous record shall be maintained for each detainee by the "Custody Officer." The detainee must also be given:

- a written notice setting out:

- the three rights of the detainee;

- the arrangements for obtaining legal advice;

- the right to a copy of the custody record;

- the caution in the terms prescribed.

- an additional written notice briefly setting out their entitlements while in custody.

Note: The detainee shall be asked to sign the custody record to acknowledge receipt of these notices. Any refusal must be recorded on the custody record.

109) See M. Berger, 'Legislating Confession Law in Great Britain: A Statutory Approach to Police Interrogation', 24 University of Michigan Journal of Law Reform (1990), 1-31; M. Berger, 'Reforming Confession Law British Style: A Decade of Experience With Adverse Inferences From Silence', 31 Columbia Human Rights Review (2000), 243-303; R. Stone, 'Exclusion of Evidence under Section 78 of the Police and Criminal Evidence Act: Practice and Principles', 3 Web Journal of Current Legal Issues (1995), 1-19; M. Redmayne, 'English Warnings', 30 Cardozo Law Review (2008), 1047-1089. The discretionary rejection of confessions in Australia has been examined by C.R. Williams in 'An Analysis of Discretionary Rejection in Relation to Confessions', 32 Melbourne University Law Review (2008), 302-331.

110) As to what qualifies as oppression, see $R v$. Mason (1988) Cr. App R 349 where it was held that deceiving a solicitor to induce him to advice his client to waive the right to silence amounted to oppression. But see $R v$. Fulling (1987) QB 426.

111) See Police and Criminal Evidence Act, Codes of Practice A-G, 2005 Edition (The Stationary Office, London, 2005). 
The above rights are mostly luxuries enjoyed by the rich in Nigeria. Many Nigerian policemen react with scorn when a suspect retains counsel. It is also possible for counsel in Nigeria to be told that he cannot see the client until the suspect's statement has been recorded or worse, counsel may be told to wait until the suspect is arraigned in court. Breach of certain provisions of Code $\mathrm{C}$ renders the confession inadmissible. ${ }^{112}$ Failure to keep contemporaneous record of an interview also vitiates a confession. ${ }^{113}$

Another enactment that has altered the law of confession in England, but which the Nigerian draftsman, in his infinite wisdom, did not appear to have considered in the Evidence Act 2011, is the Criminal Justice and Public Order Act, (CJPOA) 1994. A new introduced by Paragraph 10.2 of Code $\mathrm{C}^{114}$ of PACE cautions the suspect that he has a right not to say anything, but that it may harm his defence if he fails to mention anything which he later relies on at trial. This new warning was necessitated by Sections 34 and 35 of the Criminal Justice and Public Order Act, 1994 which permits the drawing of adverse inferences from failure to mention during interrogation facts later relied upon at trial, and failure to testify at trial. These Sections are a radical departure from the common law in that, under the common law, no comments can be made from failure to testify and the exercise of the right to remain silent at interviews was regarded as integral to the right not to self-incriminate. Section 181 of the Evidence Act 2011 permits courts in Nigeria to draw adverse inferences where an accused person fails to testify, but there is no provision in the Act (except on alibi) on adverse inference from failure to give information during investigation that the accused subsequently relied upon at trial. Thus Nigerian law is still rooted to the common law as far as adverse inferences are concerned.

\subsection{Discretionary Rejection of Confessions under the Provisions of the Evidence Act, 2011}

Sections 14 and 15 of the Evidence Act 2011 have empowered Nigerian courts exercise discretion to reject evidence. As was earlier stated, where a court finds in Nigeria that some oppressive conduct caused the accused to confess, or that other circumstances make the confession unreliable it must exclude the confession. ${ }^{115}$ Sections 14 and 15 of the Act confer discretion on courts to exclude evidence under

\footnotetext{
112) For instance, in $R v$. Samuel, supra note 106, the Court of Appeal quashed the conviction of the appellant because it was of the view that the delay to allow access to a solicitor on the basis that there was a likelihood that the solicitor might inadvertently warn other suspects was unreasonable in the circumstances of the case. It held that upon a proper consideration of the facts the trial judge might have exercised his discretion under Section 78 of PACE to exclude the confession.

113) See $R v$. Delaney (1989) Cr App R 338.

114) Supra note 111 .

115) The earliest reference to 'oppression' by the Supreme Court of Nigeria that this writer could find is in Durugo v. The State (1992) 3 NSCC 22. The appellant's allegation that electric current was applied to his penis by the police to extort his confession was rejected by the courts.
} 
certain conditions. Under Section 14 of the Act a court may exclude improperly obtained evidence where the court is of the opinion that the desirability of admitting the evidence is out-weighed by the undesirability of the manner in which the evidence was obtained. The factors that the court may consider in the determination of the desirability or undesirability are set out in Section 15 of the Act as follows:

(a) the probative value of the evidence;

(b) the importance of the evidence in the proceeding;

(c) the nature of the relevant offence;

(d) the gravity of the impropriety or contravention;

(e) whether the impropriety or contravention was deliberate or reckless;

(f) whether any other proceeding (whether or not in a court) has been or is likely to be taken in relation to the impropriety or contravention; and

(g) the difficulty, if any, of obtaining the evidence without impropriety or contravention of law.

These provisions were inspired by Section 78 of PACE. Section 78 (1) of PACE gives the court discretion to exclude evidence, if in its opinion, "having regard to the circumstances, including the circumstances in which the evidence was obtained, the admission of the evidence would have such an adverse effect on the fairness of the proceeding that the court ought not to admit it." It is submitted that by setting out the above categories, the draftsman Section 15 of the Evidence Act 2011 has unwittingly stepped into an arena where wiser angels would have hesitated to walk. The House of Lords held in $R v$. Sang, ${ }^{116}$ out of the abundance of caution, that the discretion to exclude evidence illegally obtained is anchored on the principle of fairness, but "the principle of fairness, though concerned exclusively with the use of evidence at trial, is not susceptible to categorization or classification, and is wide enough in some circumstances to embrace the way in which after the crime, evidence has been obtained from the accused."117 Writing on the discretionary rejection of evidence in Australia, Williams has cautioned that "[n]o advantage would be secured by advising investigating authorities of the precise point at which impropriety on their part would render a confession inadmissible. Equally, the variety of circumstances and the inability to anticipate all future cases render impractical any formulation of a rule (or rules) spelling out circumstances in which a confession should be rejected."118

\footnotetext{
116) (1980) AC 402.

117) Per Lord Scarman.

118) Williams, supra note 109 at 308. See also J.D. Heydo, 'Obtaining Evidence versus Protecting the Accused: Two Conflicts', The Criminal Law Review (1971) 13-34.
} 
The difficulty of obtaining the evidence without impropriety appears to permit the admissibility of evidence of agent provocateurs ${ }^{119}$ and undercover police officers, but not unreliable confessions. It is submitted that failure to administer a caution before custodial interrogation is a grave impropriety that implicates Section 15 of the E.A. 2011. But unlike PACE, 1984, there are no Codes of Practice for Police Officers on the detention, treatment and questioning of suspects in Nigeria that can serve as statutory basis for assessing impropriety or contravention. Only the Judges Rules, Criminal Procedure (Statement to Police Officers) Rules 1960, and relevant Sections of the Administration of Criminal Justice Law of Lagos State, 2011 contain opaque restrictions on the taking of confessions in Nigeria. But scant evidence exists at the moment to suggest that abuse of suspects by police officers would always automatically a confession inadmissible in Nigeria. It is also not uncommon for policemen to tell counsel to wait until the statement of the suspect is recorded before counsel can interview their clients. The records of interview of suspects are also regarded as classified information that counsel can access only with a court order. This is a grievous dent on working of the right to silence as only a Judge or magistrate can inspect police case diaries. Also, counsel can demand for the statements witnesses made to the police only for the purpose of cross examination and not for preparation before the case. ${ }^{120}$ Based on the persuasive judicial dicta arising from Section 78 of PACE in England, there is no reason why courts in Nigeria should not regard denial of access to a solicitor, or frustration of counsel from interacting with his client in private, or sitting in during interrogations as sufficiently egregious to exclude confessions, even if such confessions are true, otherwise, the courts would be complicit in the contravention of the constitutional right to silence and counsel. Failure by the police to maintain comprehensive case diaries with detailed logs should also be fatal to any confessional statement. Where the state relies on confession evidence, courts in Nigeria ,should as a practice, require evidence of the time of arrest of the suspect, evidence surrounding the questioning of such suspect, allowance for sleep of the suspect it he is detained beyond 16 hours; evidence of victuals served to the suspect; evidence of communication of the arrest to a person concerned for the welfare of the suspect as these may ensure that courts receive only confessions that are reliable, because even the restrictive Section 29(2) of the Evidence Act 2011 hinges the admissibility of confessions on reliability. In Dairo v. The State ${ }^{121}$ the Court of Appeal held that:

119) See $R v$. Sang, supra note 116 at 437.

120) See Grace Abraham Akpabio v. The State (1994) 7 NWLR (Pt 359) 635; Layonu \& Ors v. The State (1967) 1 All NLR 198 at 201.

121) (2013) All FWLR (Part 663) 1921 at 1967. 


\begin{abstract}
The circumstances in the instant case relating to the time the extrajudicial confessional statement was made and the uncontradicted assertion that the appellant did not sign after he left $\mathrm{EFCC}^{122}$ compound and was asked to come back, the act that he was kept in the office from morning till late in the evening before his statement was obtained without any reason, raises doubt and tends to give credence to appellant's claim that he was told to tell PTWı when he will cooperate while waiting for interview, this fact will appear to sap that freedom to give a voluntary statement.
\end{abstract}

In the light of the fact that Section 29 of the Evidence Act 2011 has placed the burden of proving the reliability of confessions on the prosecution, ${ }^{123}$ failure by the police to provide evidence of the time of arrest and subsequent treatment of the prisoner before, during and after the admission of culpability implicates Section 15 of the Act and ought to result in the exclusion of the confession.

\title{
5. The Rules for the Taking of Confessions in Lagos State, Nigeria
}

Lagos State, Nigeria, introduced the Administration of Criminal Justice Law, (ACJL) 2007 to replace the Criminal Procedure Code Law of the state. The ACJL, 2007 was repealed by the ACJL, No. 32, 2011. ${ }^{24}$ Section 3(2) of ACJL 2011 provides that the Police Officer or person making an arrest shall inform the person arrested of his rights to:

(a) Remain silent or avoid answering any question until after consultation with a legal practitioner or any other person of his own choice;

(b) Consult a counsel of his choice before making or writing any statement; or answering any question put to him after arrest;

(c) Refuse to answer any question or make or endorse any statement.

Section 3(2) (a) of ACJL appears to be a restatement of the provisions of Section 35(2) CFRN, 1999. But paragraphs (b) and (c) of Section 3(2) ACJL has the potential to prevent the conversion of investigations into inquisitions, and has improved Section 35(2) CFRN 1999. Section 3(3) of the ACJL further provides that the arrestee shall be informed of his right to apply for free legal representation from the Office of the Public Defender, Legal Aid Council, or any such agency. Thus, the ACJL requires that the arrestee be informed of the availability of free legal services if he cannot retain one by himself. But the most radical provision of the ACJL, 2011 on confessions is Section 9 (3) of the law. It provides as follows:

Where any person who is arrested with or without a warrant volunteers to make a Confessional Statement, the Police Officer shall ensure that the making and taking of such statement is recorded on video and the said recording and copies of it may be produced at the trial provided that in the

122) EFCC is the Economic and Financial Crimes Commission.

123) See Dairo v. The State, supra not 121 at $\mathrm{p} 1961$ paragraphs $\mathrm{C}-\mathrm{G}$.

124) The commencement date of the ACJL, 2011 was 8 August 2011. 
absence of video facility, the said statement shall be in writing in the presence of a legal practitioner of his choice.

This subsection provides two alternatives for the valid taking of a confessional statement. The statement shall either be recorded on video, or if there are no facilities for such recording, the statement shall be in writing in the presence of a legal practitioner of his choice. Oral confessions that are not recorded on video are inadmissible. This would obviate the regrettable admission of oral confessions like in Arogundare $v$ The State. ${ }^{125}$ Mandatory electronic recording of confessions has gained currency as a method of corroborating confessions, minimizing police abuse, and providing evidence of what exactly transpired in the station house between the Police and arrestees. ${ }^{126}$ The Lagos State initiative, despite limiting recording only to confessions, is a commendable step worthy of emulation by the National Assembly ${ }^{127}$ because it balances the interest of suspects and the state.

The Nigerian Police and other investigatory agencies are likely to kick against the video recording requirements of Section 9(3) of the ACJL. They may probably contend that mandatory recording is expensive, inefficient, may hamper the taking of confessions, and reduce conviction rates. However, despite initial resistance, the mandatory electronic recording of confessions that has been in operation in some states in the U.S.A. and in England and Wales, has arguably not hampered the effectiveness of the police in taking confessions and has not led to any significant reduction in the conviction rates in those countries. ${ }^{128}$

It would have been better if the ACJL, 2011 had required the video recording of every aspect of police interrogation. As rightly argued by Taslitz, video recording of the entire interrogation process is admittedly new, but it conforms to constitutional values such as "avoiding coerced or compelled confessions, protecting the innocent, and barring certain interrogation techniques as simply fundamentally unfair regardless of the suspect's guilt." ${ }^{\prime 29}$ Lagos State has thus initiated a strategy worthy of emulation by other strata of the Federation Republic of Nigeria in realizing the ideal of giving life to the constitutional rights of suspects in custody.

\footnotetext{
125) Supra note 98.

126) See T. Fisher and I. Rosen-Zvi, 'The Confessional Penalty', 30 Cardozo Law Review (2008) 871-916, at $887-888$ where they argued that electronic recording provide accurate information about the conditions in which interrogation occur.

127) The National Assembly is the supreme legislative organ in Nigeria.

128) See R.P. Mosteller, 'Police Deception Before Miranda Warnings: The Case For Per Se Prohibition of an Entirely Unjustified Practice at the Most Critical Moment', 39 Texas Tech Law Review (2007), 1239-1273, describing how the police in the USA have adopted deceptive techniques that encourages and often succeeds in making arrestees waive their right of silence and confess.

129) A.E. Taslitz, 'High Expectations and Some Wounded Hopes: The Policy and Politics of a Uniform Statute on Videotaping Custodial Interrogations', 7 Northwestern Journal of Law and Social Policy (2012), 400454. See also C. Slobogin, 'Toward Taping', 1 Ohio State Journal of Criminal Law (2003), 309-322, advancing the benefits of taping police interrogations.
} 


\section{Conclusion and Recommendation}

The right to silence enshrined in Section 35(2) of the CFRN 1999 may not be fully appreciated without its history. The interpretation and application of confession law in Nigeria that currently ignores this history manifests a superficial realization of the victory of the rule of law over the forces of oppression. Inchoate expression of and attention to the nuances of the right to silence when laying and applying rules on the admissibility of confessions concedes ground to the agents of the State who, in Nigeria, are quick to seize the short-cut of procuring confessions from suspects literally by hook or crook. Courts in Nigeria should therefore remind themselves of the rationales for the -entrenchment of the right to silence when determining the admissibility of confessions or assessing the weight to be attached to admitted confessions. These rationales were stated by the U.S. Supreme Court in Murphyv. Waterfront Commission of New York Habor ${ }^{130}$ as follows:

\footnotetext{
The privilege against self-incrimination registers an important advance in the development of our liberty-one of the great landmarks in man's struggle to make himself civilized ... It reflects many of our fundamental values and most noble aspirations: our unwillingness to subject those suspected of crime to the cruel trilemma of self-accusation, perjury and contempt; our preference for an accusatorial rather than inquisitorial system of criminal justice: our fear that self-incriminating statements will be elicited by inhuman treatment and abuses: our sense of fair play which dictates a fair state-individual balance by requiring the government... in its contest with the individual to shoulder the entire load...; our respect for the inviolability of the human personality ...; or distrust of self-deprecatory statements; and our realization that the privilege while sometimes a "shelter to the guilty", is often "a protection to the innocent."131
}

The above rationales are more extensive than the principles of admissibility of confessions in Section 29 of the Evidence Act 2011. The restriction of the factors that ought to guide the reception of confessions in evidence to the provisions of the Evidence Act negates the ideology of a political system that is founded on individual autonomy. Where the State alleges that an individual has committed a crime, it must bear the entire load of proving his guilt. The State can fairly only do so by proper methods, not by using oppressive means for the individual to do the job for the government. There is strong evidence that the extortion of confessions by state officials in Nigeria are not isolated events but a systemic problem. The fear that many policemen in Nigeria adopt the shortcut of eliciting confessions instead of adopting scientific methods of investigation is real. Courts in Nigeria are justified if they develop a practice of distrusting confessions offered by the government.

The legislature could have introduced clearly defined rules to regulate the stages of the treatment of arrestees and detainees when it repealed the Evidence Act 1990 and introduced the Evidence Act 2011. There is no sound reason why the

130) 378 U.S. 53,55 (1964).

131) Ibid., per Mr. Justice Goldberg. 
legislature borrowed Section 76 of PACE 1984 without making room for the introduction of Codes of Practice the way the British parliament did in Section 66 of PACE. Also, Nigeria adopted the constitutional framework of the United States in the CFRN 1999, but it seems contradictory that courts in Nigeria have not adopted and adapted the reasoning of the U.S Supreme Court in Haynes $v$. Washington and Miranda v. Arizona to suit local circumstances. The reasoning in the two cases accords a fair constitutional narrative to the admissibility of confessions and gives meaning to the constitutional right to silence and freedom from compelled testimony. It is plausible that a constitutional flavour to confession law provides better guidance to lower courts, deter or minimize police abuse of detainees, and vindicate the dignity of suspects in custody. There is no sound normative basis to regard confessions as the strongest evidence of guilt if the processes of questioning of suspects are not regulated by constitutional principles. Rules of admissibility of confessions that ignore the evidential character of the right to silence and freedom from compelled self-incrimination are charters for torturers.

The rules of admissibility of confessions in the Evidence Act 2011 are important but the National Assembly and courts should not forget that those rules and the constitutional right to silence drive their force from man's subjugation of the oppressive arrogation and abuse of governmental powers. Therefore, courts in Nigeria should regard denial of access to a solicitor, or frustration of counsel from interacting with clients in private, or sitting in during interrogations as sufficiently egregious to exclude confessions, even if such confessions are true, otherwise, the courts would be complicit in the contravention of the constitutional rights to silence and counsel. Failure by the police to maintain comprehensive case diaries with time and incident logs, records of every action taken should also be fatal to the admissibility of confessions. Such failure breach international best practices for police forces. Where the state relies on confession evidence, courts in Nigeria should, as a practice, require evidence of the time of arrest of the suspect, evidence surrounding the questioning of such suspect, allowance for sleep of the suspect if he is detained beyond 16 hours; evidence of victuals served to the suspect; evidence of communication of the arrest to a person concerned for the welfare of the suspect, etc. Failure of the police to provide evidence of any of these should be presumed as suggestive of coercion. The exclusion of such confessions also frees the courts from inherent complicity in such breaches of the rule of law, or due process. Interrogations should be recorded on video, or conducted in the presence of counsel as provided by the ACJL of Lagos State, 2011 as this requirement balances state-individual interests. 